\title{
Nutrition for Sarcopenia
}

\author{
Hidekatsu Yanai
}

\begin{abstract}
Aging-related sarcopenia means that muscle mass, strength, and physical performance tend to decline with age, and malnutrition is associated with sarcopenia. Therefore, nutritional interventions may make an important contribution to prevent the development of sarcopenia. Here I reviewed published articles about the effects of nutritional factors on sarcopenia in elderly people. A growing body of evidence suggests that metabolic factors associated with obesity and diabetes induce the progression of sarcopenia. However, the effectiveness and safety of caloric restriction for sarcopenia remained unclear. Protein intake and physical activity are the main anabolic stimuli for muscle protein synthesis. As optimal dietary protein intake, $1.0-1.2 \mathrm{~g} / \mathrm{kg}$ (body weight)/day with an optimal repartition over each daily meal or $25-30 \mathrm{~g}$ of high quality protein per meal were recommended to prevent sarcopenia, which was supported by some observational studies. Protein supplementation using cheese and milk protein, essential amino acids, leucine, beta-hydroxy-beta-methylbutyrate and vitamin $\mathrm{D}$ has been investigated as a potential supplement to improve muscle quality in sarcopenic elderly people.
\end{abstract}

Keywords: Beta-hydroxy-beta-methylbutyrate; Energy restriction; Leucine; Protein intake; Sarcopenia

\section{Introduction}

The number of elderly people has been rapidly increasing in Japan. The growing number of elderly people has compelled us to focus on aging-related sarcopenia. Sarcopenia indicates that muscle mass, strength, and physical performance tend to decline with age, therefore sarcopenia becomes increasingly prevalent with age [1-3]. As sarcopenia is a major predictor of frailty, hip fracture, disability and mortality in elderly per-

Manuscript accepted for publication October 12, 2015

Department of Internal Medicine, National Center for Global Health and Medicine Kohnodai Hospital, 1-7-1 Kohnodai, Chiba 272-8516, Japan. Email: dyanai@hospk.ncgm.go.jp

doi: http://dx.doi.org/10.14740/jocmr2361w sons [1-3], the development of effective management to treat it is eagerly awaited. Malnutrition is one of factors which induce sarcopenia [3]. Nutritional interventions may make an important contribution to avenues for prevention of sarcopenia. However, nutritional management for sarcopenia remains largely unknown. Here I reviewed published articles about the effects of nutritional factors on sarcopenia in elderly people.

\section{The Association Between Energy Intake and the Development of Sarcopenia}

A growing body of evidence suggests that metabolic factors associated with obesity and diabetes induce the progression of sarcopenia [4]. Recently, the age-related change in the body composition such as a combination of excess weight and reduced muscle mass/strength is defined as sarcopenic obesity [5]. Sarcopenic obesity is associated with the upregulation of inflammatory cytokines [5], which further deteriorates sarcopenia [6]. Is energy restriction (ER) effective to prevent obesity/diabetes-related sarcopenia? In the systematic review using 52 studies including exercise (EX), ER, or ER + EX groups, $81 \%$ and $39 \%$ of the ER and ER + EX groups, respectively, lost over $15 \%$ of body weight as fat-free mass (FFM) [7]. Study participants had to have a mean age of $\geq 50$ years and mean body mass index (BMI) of $\geq 25 \mathrm{~kg} / \mathrm{m}^{2}$. Studies that had very low calorie diets ( $\leq 800$ calories per day) were excluded. This study suggests that EX preserves FFM after moderate ER, and also indicates that ER induces FFM loss even in obese people. Normandin et al identified 19 published papers from 10 randomized controlled trials (RCTs) ranging from 3 to 18 months that reported independent effects of a caloric restriction (CR) on the health benefits in adults with a mean age of $\geq 65$ years [8]. They concluded that the risk-to-benefit ratio of CR for the treatment of obesity in elderly adults remains unclear. We should determine the adequate energy intake to prevent or treat sarcopenia by performing further studies in the future.

\section{The Association Between Protein Intake and the Development of Sarcopenia}

In the cross-sectional study combined five datasets $(\mathrm{n}=900)$, $77 \%$ of all participants had lower than recommended protein 
Table 1. Clinical Trials to Study Effects of Protein, Amino Acids, Leucine, Vitamin D, HMB Intake on Sarcopenia

\begin{tabular}{|c|c|c|c|}
\hline Authors & Subjects & Study design & Resuts/Conclusions \\
\hline $\begin{array}{l}\text { Aleman-Mateo } \\
\text { et al [18] }\end{array}$ & $\begin{array}{l}\text { Patients with } \\
\text { sarcopenia, } \geq 60 \\
\text { years }(n=40)\end{array}$ & $\begin{array}{l}\text { The intervention group received } 210 \mathrm{~g} / \text { day } \\
\text { of ricotta cheese plus the habitual diet, while } \\
\text { the control group followed the habitual diet } \\
\text { with no additional intervention for } 3 \text { months. }\end{array}$ & $\begin{array}{l}\text { The adding daily } 210 \mathrm{~g} \text { of ricotta cheese to the } \\
\text { habitual diet improved the markers of sarcopenia in } \\
\text { subjects without a pronounced loss of skeletal } \\
\text { muscle mass. }\end{array}$ \\
\hline Tieland et al [19] & $\begin{array}{l}\text { Frail elderly people } \\
(\mathrm{n}=65)\end{array}$ & $\begin{array}{l}\text { Subjects were randomly allocated } \\
\text { to either daily protein or placebo } \\
\text { supplementation ( } 15 \mathrm{~g} \text { milk protein at } \\
\text { breakfast and lunch), for } 24 \text { weeks. }\end{array}$ & $\begin{array}{l}\text { Dietary milk protein supplementation improved } \\
\text { physical performance, but did not increase skeletal } \\
\text { muscle mass in frail elderly people. }\end{array}$ \\
\hline Walrand et al [20] & $\begin{array}{l}\text { Healthy elderly } \\
\text { men }(71.8 \pm 2.4 \\
(\text { mean } \pm \text { SD }) \\
\text { years, } \mathrm{n}=31)\end{array}$ & $\begin{array}{l}\text { Adequate-protein or high-protein diet } \\
\text { together with the protein source as caseins } \\
\text { or soluble milk proteins was provided for } 10 \\
\text { days. }\end{array}$ & $\begin{array}{l}\text { Fast-digesting soluble milk proteins improved } \\
\text { postprandial muscle protein synthesis in elderly } \\
\text { subjects. }\end{array}$ \\
\hline Shahar et al [21] & $\begin{array}{l}\text { Sarcopenic elderly } \\
\text { Malays aged } 60- \\
74 \text { years }(n=65)\end{array}$ & $\begin{array}{l}\text { Subjects were assigned to the control group, } \\
\text { exercise group, protein supplementation } \\
\text { group, or the combination of exercise and } \\
\text { protein supplementation group for } 12 \text { weeks. }\end{array}$ & $\begin{array}{l}\text { The exercise program improved muscle } \\
\text { strength and body composition, while protein } \\
\text { supplementation reduced body weight and } \\
\text { increased upper body strength. }\end{array}$ \\
\hline Dillon et al [23] & $\begin{array}{l}\text { Elderly women }(68 \\
\pm 2 \text { years })(n=14)\end{array}$ & $\begin{array}{l}\text { Subjects were assigned to receive } \\
\text { either placebo }(n=7) \text {, or } 15 \mathrm{~g} \text { EAA/ } \\
\text { day }(n=7) \text { for } 3 \text { months. }\end{array}$ & $\begin{array}{l}\text { EAA improved LM and basal muscle } \\
\text { protein synthesis in elderly individuals. }\end{array}$ \\
\hline $\begin{array}{l}\text { Borsheim } \\
\text { et al }[26]\end{array}$ & $\begin{array}{l}\text { Glucose intolerant } \\
\text { subjects }(67.0 \pm \\
5.6 \text { years, seven } \\
\text { females, five males) }\end{array}$ & $\begin{array}{l}\text { Subjects ingested } 11 \mathrm{~g} \text { of a nutritional } \\
\text { supplement containing EAA + arginine } \\
\text { twice a day, between meals for } 16 \text { weeks. }\end{array}$ & $\begin{array}{l}\text { Supplementation of the diet with EAA }+ \text { arginine } \\
\text { improved LM, strength and physical function. }\end{array}$ \\
\hline Coker et al [27] & $\begin{array}{l}\text { Elderly individuals } \\
(\mathrm{n}=12)\end{array}$ & $\begin{array}{l}\text { Caloric restriction diet utilizing equivalent } \\
\text { caloric meal replacements ( } 800 \mathrm{kcal} / \text { day): } \\
\text { 1) EAAMR or } 2 \text { ) CMR in conjunction with } \\
400 \mathrm{kcal} \text { of solid food that totaled } 1,200 \\
\mathrm{kcal} / \text { day designed to induce } 7 \% \text { weight loss. }\end{array}$ & $\begin{array}{l}\text { Both groups lost about } 7 \% \text { of total body weight. } \\
\text { While EAAMR did not promote a significant } \\
\text { preservation of LM, the reduction in adipose tissue } \\
\text { was greater in EAAMR compared to CMR. }\end{array}$ \\
\hline Bukhari et al [28] & $\begin{array}{l}\text { Elderly women } \\
(66 \pm 2.5 \text { years; } \\
\mathrm{n}=8 / \text { group })\end{array}$ & $\begin{array}{l}\text { Whey protein or novel low-dose } \\
\text { leucine-enriched EAA ( } 3 \mathrm{~g}, 40 \% \\
\text { leucine), single-dose administration. }\end{array}$ & $\begin{array}{l}\text { There was no difference in muscle anabolism } \\
\text { between whey protein and novel low-dose } \\
\text { leucine-enriched EAA. }\end{array}$ \\
\hline $\begin{array}{l}\text { Cangussu } \\
\text { et al [29] }\end{array}$ & $\begin{array}{l}\text { Postmenopausal } \\
\text { women }(50-65 \\
\text { years) with a } \\
\text { history of falls } \\
(\mathrm{n}=160)\end{array}$ & $\begin{array}{l}\text { Subjects were randomized into vitamin } \\
\text { D group consisting of patients receiving } \\
\text { vitamin D } 1,000 \text { IU/day orally }(n=80) \text { or } \\
\text { placebo group }(n=80) \text { for } 9 \text { months. }\end{array}$ & $\begin{array}{l}\text { In the vitamin D group, there was significant } \\
\text { increase in muscle strength }(+25.3 \%) \text { of the lower } \\
\text { limbs by chair rising test. In the placebo group, } \\
\text { there was considerable loss }(-6.8 \%) \text { in LM. }\end{array}$ \\
\hline
\end{tabular}


Table 1. Clinical Trials to Study Effects of Protein, Amino Acids, Leucine, Vitamin D, HMB Intake on Sarcopenia - (continued)

\begin{tabular}{|c|c|c|c|}
\hline Authors & Subjects & Study design & Resuts/Conclusions \\
\hline $\begin{array}{l}\text { Verschueren } \\
\text { et al [30] }\end{array}$ & $\begin{array}{l}\text { Institutionalized } \\
\text { elderly females } \\
\text { aged over } 70 \text { years } \\
\text { (mean age } 79.6 \\
\text { years) }(\mathrm{n}=113)\end{array}$ & $\begin{array}{l}\text { In a } 2 \times 2 \text { factorial-design trial, subjects } \\
\text { were randomly assigned either to a whole- } \\
\text { body vibration or a no-training group, } \\
\text { receiving either a conventional dose ( } 880 \\
\text { IU/day) or a high dose ( } 1,600 \mathrm{IU} / \text { day) of } \\
\text { vitamin D. }\end{array}$ & $\begin{array}{l}\text { After } 6 \text { months of treatment, dynamic muscle } \\
\text { strength improved significantly in all groups. A } \\
\text { higher dose of vitamin D did not provide additional } \\
\text { musculoskeletal benefit compared with } \\
\text { conventional doses. }\end{array}$ \\
\hline Bauer et al [32] & $\begin{array}{l}\text { Sarcopenic } \\
\text { primarily } \\
\text { independent-living } \\
\text { elderly adults } \\
(\mathrm{n}=380)\end{array}$ & $\begin{array}{l}\text { The active group }(\mathrm{n}=184) \text { received a } \\
\text { vitamin } \mathrm{D} \text { and leucine-enriched whey } \\
\text { protein nutritional supplement to consume } \\
\text { twice daily for } 13 \text { weeks. The control group } \\
(\mathrm{n}=196) \text { received an isocaloric control } \\
\text { product to consume twice daily for } 13 \\
\text { weeks. }\end{array}$ & $\begin{array}{l}\text { The } 13 \text {-week intervention of a vitamin D and } \\
\text { leucine-enriched whey protein oral nutritional } \\
\text { supplement resulted in improvements in muscle } \\
\text { mass and lower-extremity function among } \\
\text { sarcopenic elderly adults. }\end{array}$ \\
\hline $\begin{array}{l}\text { Verreijen et } \\
\text { al [33] }\end{array}$ & $\begin{array}{l}\text { Obese elderly } \\
\text { adults }(63 \pm 5.6 \\
\text { years; body mass } \\
\text { index, } 33 \pm 4.4 \\
\left.\mathrm{~kg} / \mathrm{m}^{2}, \mathrm{n}=80\right)\end{array}$ & $\begin{array}{l}\text { All subjects followed a hypocaloric diet } \\
\text { (-600 kcal/day) and performed resistance } \\
\text { training } 3 \text { times/week. A high whey } \\
\text { protein-, leucine-, and vitamin D-enriched } \\
\text { supplement including a mix of other macro- } \\
\text { and micronutrients ( } 150 \mathrm{kcal}, 21 \mathrm{~g} \text { protein; } \\
10 \text { times/week) or an isocaloric control. }\end{array}$ & $\begin{array}{l}\text { A high whey protein-, leucine-, and vitamin } \\
\text { D-enriched supplement compared with isocaloric } \\
\text { control preserved muscle mass. }\end{array}$ \\
\hline Hsieh et al [34] & $\begin{array}{l}\text { Bed-ridden } \\
\text { elderly nursing } \\
\text { home residents } \\
\text { receiving tube } \\
\text { feeding }(\mathrm{n}=79)\end{array}$ & $\begin{array}{l}\text { Subjects were randomly assigned to HMB } \\
(\mathrm{n}=39,2 \mathrm{~g} \text { /day) or control group }(\mathrm{n}=40) \\
\text { for } 4 \text { weeks. }\end{array}$ & $\begin{array}{l}\text { HMB supplementation for } 2 \text { - } 4 \text { weeks could } \\
\text { reduce muscle breakdown in bed-ridden elderly } \\
\text { nursing home residents receiving tube feeding. }\end{array}$ \\
\hline Baier et al [36] & $\begin{array}{l}\text { Elderly }(76 \pm 1.6 \\
\text { years) women } \\
(\mathrm{n}=39) \text { and } \\
\text { men }(\mathrm{n}=38)\end{array}$ & $\begin{array}{l}\text { Participants were randomly assigned to } \\
\text { either an isonitrogenous control-supplement } \\
(\mathrm{n}=37) \text { or a treatment-supplement (HMB/ } \\
\text { arginine/lysine) }(\mathrm{n}=40) \text { for } 1 \text { year. }\end{array}$ & $\begin{array}{l}\text { Consumption of a simple amino acid-related } \\
\text { cocktail increased protein turnover and LM in } \\
\text { elderly individuals in a year-long study. }\end{array}$ \\
\hline
\end{tabular}

AAS: amino acid supplementation; CMR: competitive meal replacement; EAA: essential amino acids; EAAMR: whey protein + essential amino acid meal replacement; HE: health education; HMB: beta-hydroxy-beta-methylbutyrate; LM: lean mass.

intake [9], indicating the existence of insufficient protein intake in heterogeneous elderly populations.

Protein intake and physical activity are the main anabolic stimuli for muscle protein synthesis. Aging causes loss of various anabolic signals to muscle that are present in young people [10]. Such "anabolic resistance" is associated with the development of sarcopenia [10]. Amino acids alone stimulate muscle protein synthesis in the elderly. However, mixed nutritional supplementation failed to improve muscle mass. Volpi et al found that the response of muscle protein anabolism to hyperaminoacidemia with endogenous hyperinsulinemia is impaired in healthy elderly people [11].
How much protein should elderly people with anabolic resistance ingest? Rizzoli reported the recommendations for optimal dietary protein intake are daily $1.0-1.2 \mathrm{~g} / \mathrm{kg}$ (body weight) with an optimal repartition over each daily meal to prevent sarcopenia [12]. Paddon-Jones et al proposed a dietary plan that includes 25 - $30 \mathrm{~g}$ of high quality protein per meal as dietary protein recommendations for the prevention of sarcopenia [13].

Bopp et al investigated the association between dietary protein intake and loss of lean mass (LM) during a 20-week weight loss intervention in postmenopausal women [14]. Protein intake averaged $0.62 \mathrm{~g} / \mathrm{kg} /$ day $(0.47-0.8 \mathrm{~g} / \mathrm{kg} /$ day $)$. Par- 
ticipants who consumed higher amounts of dietary protein lost less LM; however, these participants $(0.8 \mathrm{~g} / \mathrm{kg} / \mathrm{day})$ also lost LM. These results suggested that an inadequate protein intake may be associated with LM loss, and daily protein intake $\leq 0.8$ $\mathrm{g} / \mathrm{kg}$ was not sufficient to prevent LM loss in postmenopausal women.

Houston et al studied to determine the association between dietary protein and changes in total LM in elderly, communitydwelling men and women [15]. Energy-adjusted protein intake was associated with 3 -year changes in LM. Participants in the highest quintile of protein intake $(1.2 \mathrm{~g} / \mathrm{kg} /$ day $)$ lost approximately $40 \%$ less LM than did those in the lowest quintile of protein intake $(0.8 \mathrm{~g} / \mathrm{kg} /$ day $)$.

In Japan, Kobayashi et al examined the association of protein and amino acid intake with frailty among elderly Japanese women [16]. Subjects categorized to the third $(69.8-76.1 \mathrm{~g} /$ day), fourth (76.1 - 84.3 g/day), and fifth quintiles (76.1 - 84.3 $\mathrm{g}$ /day) of total protein intake showed significantly lower odds ratios than those to the first quintile $(\leq 62.9 \mathrm{~g} /$ day $)$.

Recently the study was undertaken to evaluate differences in protein intake in women with or without sarcopenia [17]. Elderly women older than 65 years with sarcopenia $(n=35)$ and without sarcopenia $(n=165)$ participated in the study. Muscle mass was significantly higher in women who had protein intake $>1.2 \mathrm{~g} / \mathrm{kg} /$ day. Protein and energy intake were significant predictors of muscle mass.

These results agreed with the recommendation for protein intake such as $1.0-1.2 \mathrm{~g} / \mathrm{kg} /$ day (daily $60-72 \mathrm{~g}$ for $60 \mathrm{~kg}$ weighted subjects) and $25-30 \mathrm{~g}$ of high quality protein per meal (daily $75-90 \mathrm{~g}$ ).

\section{Clinical Trials to Study Effects of Nutritional Factors on Sarcopenia}

Clinical trials to study effects of nutritional factors on sarcopenia were shown in Table 1 [18-36]. The adding daily $210 \mathrm{~g}$ of ricotta cheese to the habitual diet improved the markers of sarcopenia in subjects without a pronounced loss of skeletal muscle mass [18]. Dietary milk protein supplementation improved physical performance, but did not increase skeletal muscle mass in frail elderly people [19]. Fast-digestive soluble milk protein supplement for 10 days overcame muscle anabolic resistance and improved postprandial muscle protein synthesis in healthy elderly men [20]. In 65 sarcopenic elderly Malays aged 60 - 74 years, there was an increase in FFM $(+5.7 \%)$ in the EX group after 12 weeks. The highest increments in lower body strength was observed in the protein supplementation group $(73.2 \%)$ [21].

One hundred fifty-five sarcopenic women aged 75 and older were randomly assigned to EX and amino acid supplementation, EX, amino acid supplementation, or health education. EX and amino acid supplementation together was effective in enhancing not only muscle strength, but also combined variables of muscle mass and walking speed in sarcopenic women [22]. Daily ingestion of $15 \mathrm{~g}$ essential amino acids (EAA) improved LM and basal muscle protein synthesis in elderly individuals [23]. Ingestion of $8 \mathrm{~g}$ of EAA snacks twice a day, significantly increased LM after 6 months and more consistently after 18 months [24]. An oral amino acid supplement improved ambulatory capacity and maximal isometric muscle strength in elderly subjects [25]. Supplementation of the diet with EAA plus arginine also improved LM, strength and physical function compared to baseline values in glucose intolerant elderly individuals [26]. Coker et al recruited and randomized 12 elderly individuals to an 8-week, CR diet utilizing equivalent caloric meal replacements $(800 \mathrm{kcal} /$ day $): 1)$ whey protein + EAA meal replacement (EAAMR) or 2) competitive meal replacement $(\mathrm{CMR})$ in conjunction with $400 \mathrm{kcal}$ of solid food that totaled 1,200 $\mathrm{kcal} /$ day designed to induce $7 \%$ weight loss [27]. Both groups lost about $7 \%$ of total body weight. While EAAMR did not promote a significant preservation of LM, the reduction in adipose tissue was greater in EAAMR compared to CMR. These results indicate that quality of protein and energy intake are associated with prevention of sarcopenia.

Aging is associated with changes in the muscle protein metabolism response to a meal, due to alterations in the response to endogenous hormones. The older muscle is still able to respond to amino acids such as leucine, leucine initiates mRNA translation, which is still present in elderly people [37]. Longterm EAA supplementation including excess leucine may be a useful tool for the prevention and treatment of sarcopenia [37]. Beta-hydroxy-beta-methylbutyrate (HMB), a metabolite of the branched-chain amino acid leucine, has been investigated as a potential supplement to improve muscle quality [38].

Bukhari et al performed a single-dose administration (whey protein or novel low-dose leucine-enriched EAA (3 g, $40 \%$ leucine)) [28]. However, they did not show the difference in muscle anabolism between whey protein and novel low-dose leucine-enriched EAA by a single-dose administration [28].

Vitamin D has been known to have a role in skeletal muscle health [39]. Further, regular EX is the strategy found to consistently prevent frailty and improve sarcopenia and physical function in elderly adults [40]. Resistance EX training is effective in increasing muscle mass and strength [40].

The supplementation of vitamin D alone provided significant protective effect against the occurrence of sarcopenia and significant increases in muscle strength in postmenopausal women [29]. In a $2 \times 2$ factorial-design trial, subjects were randomly assigned either to a whole-body vibration (WBV) or a no-training group, receiving either a conventional dose (880 $\mathrm{IU} /$ day) or a high dose (1,600 IU/day) of vitamin D [30]. A higher dose of vitamin D did not provide additional musculoskeletal benefit compared with conventional doses.

A protein-enriched diet equivalent to $1.3 \mathrm{~g} / \mathrm{kg} /$ day achieved through lean red meat is safe and effective for enhancing the effects of progressive resistance training on LM and muscle strength [31]. The 13-week intervention of a vitamin D and leucine-enriched whey protein oral nutritional supplement resulted in improvements in muscle mass and lower-extremity function among sarcopenic elderly adults [32]. A high whey protein-, leucine-, and vitamin D-enriched supplement preserved muscle mass during intentional weight loss in obese elderly adults [33].

HMB supplementation for 2 - 4 weeks could reduce muscle breakdown in bed-ridden elderly nursing home residents 
receiving tube feeding [34]. Daily supplementation of HMB, arginine, and lysine for 12 weeks beneficially altered measurements of muscle functionality, strength, FFM, and protein synthesis [35]. Consumption of a simple amino acid-related cocktail (HMB, arginine and lysine) increased protein turnover and LM in elderly individuals in a year-long study [36].

\section{Conclusion}

I reviewed published articles about the effects of nutritional factors on sarcopenia. Epidemiological studies suggested that a low protein intake is associated with sarcopenia. The effectiveness and safety of ER for sarcopenic obesity remains unclear. As optimal dietary protein intake, daily $1.0-1.2 \mathrm{~g} / \mathrm{kg}$ with an optimal repartition over each daily meal or $25-30 \mathrm{~g}$ of high quality protein per meal were recommended to prevent sarcopenia, which was supported by some observational studies. Cheese and milk protein, EAA, leucine, HMB and vitamin $\mathrm{D}$ have been investigated as a potential supplement to improve muscle quality in sarcopenic elderly people. Some studies showed the effectiveness of these nutritional factors for sarcopenia. However, we should consider the appropriate concomitant energy intake, the combination of these factors and the combination with physical activities, to develop a better management for sarcopenia. Further studies, preferably with larger numbers of elderly subjects, will be needed.

\section{Competing Interests}

The authors declare that they have no competing interests.

\section{Funding}

This work was funded by a grant from the National Center for Global Health and Medicine (26-112).

\section{References}

1. Santilli V, Bernetti A, Mangone M, Paoloni M. Clinical definition of sarcopenia. Clin Cases Miner Bone Metab. 2014;11(3):177-180.

2. Cooper C, Dere W, Evans W, Kanis JA, Rizzoli R, Sayer AA, Sieber CC, et al. Frailty and sarcopenia: definitions and outcome parameters. Osteoporos Int. 2012;23(7):1839-1848.

3. Kim JS, Wilson JM, Lee SR. Dietary implications on mechanisms of sarcopenia: roles of protein, amino acids and antioxidants. J Nutr Biochem. 2010;21(1):1-13.

4. Anton SD, Karabetian C, Naugle K, Buford TW. Obesity and diabetes as accelerators of functional decline: can lifestyle interventions maintain functional status in high risk older adults? Exp Gerontol. 2013;48(9):888-897.

5. Sakuma K, Yamaguchi A. Sarcopenic obesity and endocrinal adaptation with age. Int $\mathrm{J}$ Endocrinol.
2013;2013:204164.

6. Jensen GL. Inflammation: roles in aging and sarcopenia. JPEN J Parenter Enteral Nutr. 2008;32(6):656-659.

7. Weinheimer EM, Sands LP, Campbell WW. A systematic review of the separate and combined effects of energy restriction and exercise on fat-free mass in middle-aged and older adults: implications for sarcopenic obesity. Nutr Rev. 2010;68(7):375-388.

8. Normandin E, Houston DK, Nicklas BJ. Caloric restriction for treatment of geriatric obesity: Do the benefits outweigh the risks? Curr Nutr Rep. 2015;4(2):143-155.

9. Jyvakorpi SK, Pitkala KH, Puranen TM, Bjorkman MP, Kautiainen H, Strandberg TE, Soini H, et al. Low protein and micronutrient intakes in heterogeneous older population samples. Arch Gerontol Geriatr. 2015;61(3):464471.

10. Roubenoff R. Catabolism of aging: is it an inflammatory process? Curr Opin Clin Nutr Metab Care. 2003;6(3):295299.

11. Volpi E, Mittendorfer B, Rasmussen BB, Wolfe RR. The response of muscle protein anabolism to combined hyperaminoacidemia and glucose-induced hyperinsulinemia is impaired in the elderly. J Clin Endocrinol Metab. 2000;85(12):4481-4490.

12. Rizzoli R. Nutrition and Sarcopenia. J Clin Densitom. 2015.

13. Paddon-Jones D, Rasmussen BB. Dietary protein recommendations and the prevention of sarcopenia. Curr Opin Clin Nutr Metab Care. 2009;12(1):86-90.

14. Bopp MJ, Houston DK, Lenchik L, Easter L, Kritchevsky $\mathrm{SB}$, Nicklas BJ. Lean mass loss is associated with low protein intake during dietary-induced weight loss in postmenopausal women. J Am Diet Assoc. 2008;108(7):12161220.

15. Houston DK, Nicklas BJ, Ding J, Harris TB, Tylavsky FA, Newman AB, Lee JS, et al. Dietary protein intake is associated with lean mass change in older, community-dwelling adults: the Health, Aging, and Body Composition (Health ABC) Study. Am J Clin Nutr. 2008;87(1):150155.

16. Kobayashi S, Asakura K, Suga H, Sasaki S. High protein intake is associated with low prevalence of frailty among old Japanese women: a multicenter cross-sectional study. Nutr J. 2013;12:164.

17. Genaro Pde S, Pinheiro Mde M, Szejnfeld VL, Martini LA. Dietary protein intake in elderly women: association with muscle and bone mass. Nutr Clin Pract. 2015;30(2):283-289.

18. Aleman-Mateo H, Macias L, Esparza-Romero J, Astiazaran-Garcia H, Blancas AL. Physiological effects beyond the significant gain in muscle mass in sarcopenic elderly men: evidence from a randomized clinical trial using a protein-rich food. Clin Interv Aging. 2012;7:225234.

19. Tieland M, van de Rest O, Dirks ML, van der Zwaluw N, Mensink M, van Loon LJ, de Groot LC. Protein supplementation improves physical performance in frail elderly people: a randomized, double-blind, placebo-controlled trial. J Am Med Dir Assoc. 2012;13(8):720-726. 
20. Walrand S, Gryson C, Salles J, Giraudet C, Migne C, Bonhomme C, Le Ruyet $\mathrm{P}$, et al. Fast-digestive protein supplement for ten days overcomes muscle anabolic resistance in healthy elderly men. Clin Nutr. 2015.

21. Shahar S, Kamaruddin NS, Badrasawi M, Sakian NI, Abd Manaf Z, Yassin Z, Joseph L. Effectiveness of exercise and protein supplementation intervention on body composition, functional fitness, and oxidative stress among elderly Malays with sarcopenia. Clin Interv Aging. 2013;8:1365-1375.

22. Kim HK, Suzuki T, Saito K, Yoshida H, Kobayashi H, Kato H, Katayama M. Effects of exercise and amino acid supplementation on body composition and physical function in community-dwelling elderly Japanese sarcopenic women: a randomized controlled trial. J Am Geriatr Soc. 2012;60(1):16-23.

23. Dillon EL, Sheffield-Moore M, Paddon-Jones D, Gilkison C, Sanford AP, Casperson SL, Jiang J, et al. Amino acid supplementation increases lean body mass, basal muscle protein synthesis, and insulin-like growth factorI expression in older women. J Clin Endocrinol Metab. 2009;94(5):1630-1637.

24. Solerte SB, Gazzaruso C, Bonacasa R, Rondanelli M, Zamboni M, Basso C, Locatelli E, et al. Nutritional supplements with oral amino acid mixtures increases wholebody lean mass and insulin sensitivity in elderly subjects with sarcopenia. Am J Cardiol. 2008;101(11A):69E-77E.

25. Scognamiglio R, Piccolotto R, Negut C, Tiengo A, Avogaro A. Oral amino acids in elderly subjects: effect on myocardial function and walking capacity. Gerontology. 2005;51(5):302-308.

26. Borsheim E, Bui QU, Tissier S, Kobayashi H, Ferrando AA, Wolfe RR. Effect of amino acid supplementation on muscle mass, strength and physical function in elderly. Clin Nutr. 2008;27(2):189-195.

27. Coker RH, Miller S, Schutzler S, Deutz N, Wolfe RR. Whey protein and essential amino acids promote the reduction of adipose tissue and increased muscle protein synthesis during caloric restriction-induced weight loss in elderly, obese individuals. Nutr J. 2012;11:105.

28. Bukhari SS, Phillips BE, Wilkinson DJ, Limb MC, Rankin D, Mitchell WK, Kobayashi H, et al. Intake of low-dose leucine-rich essential amino acids stimulates muscle anabolism equivalently to bolus whey protein in older women at rest and after exercise. Am J Physiol Endocrinol Metab. 2015;308(12):E1056-1065.

29. Cangussu LM, Nahas-Neto J, Orsatti CL, Bueloni-Dias FN, Nahas EA. Effect of vitamin D supplementation alone on muscle function in postmenopausal women: a randomized, double-blind, placebo-controlled clinical trial. Osteoporos Int. 2015;26(10):2413-2421.

30. Verschueren SM, Bogaerts A, Delecluse C, Claessens AL, Haentjens P, Vanderschueren D, Boonen S. The effects of whole-body vibration training and vitamin D supplementation on muscle strength, muscle mass, and bone density in institutionalized elderly women: a 6-month randomized, controlled trial. J Bone Miner Res. 2011;26(1):42-49.

31. Daly RM, O'Connell SL, Mundell NL, Grimes CA, Dunstan DW, Nowson CA. Protein-enriched diet, with the use of lean red meat, combined with progressive resistance training enhances lean tissue mass and muscle strength and reduces circulating IL-6 concentrations in elderly women: a cluster randomized controlled trial. Am J Clin Nutr. 2014;99(4):899-910.

32. Bauer JM, Verlaan S, Bautmans I, Brandt K, Donini LM, Maggio M, McMurdo ME, et al. Effects of a Vitamin D and Leucine-Enriched Whey Protein Nutritional Supplement on Measures of Sarcopenia in Older Adults, the PROVIDE Study: A Randomized, DoubleBlind, Placebo-Controlled Trial. J Am Med Dir Assoc. 2015;16(9):740-747.

33. Verreijen AM, Verlaan S, Engberink MF, Swinkels S, de Vogel-van den Bosch J, Weijs PJ. A high whey protein-, leucine-, and vitamin D-enriched supplement preserves muscle mass during intentional weight loss in obese older adults: a double-blind randomized controlled trial. Am J Clin Nutr. 2015;101(2):279-286.

34. Hsieh LC, Chow CJ, Chang WC, Liu TH, Chang CK. Effect of beta-hydroxy-beta-methylbutyrate on protein metabolism in bed-ridden elderly receiving tube feeding. Asia Pac J Clin Nutr. 2010;19(2):200-208.

35. Flakoll P, Sharp R, Baier S, Levenhagen D, Carr C, Nissen S. Effect of beta-hydroxy-beta-methylbutyrate, arginine, and lysine supplementation on strength, functionality, body composition, and protein metabolism in elderly women. Nutrition. 2004;20(5):445-451.

36. Baier S, Johannsen D, Abumrad N, Rathmacher JA, Nissen S, Flakoll P. Year-long changes in protein metabolism in elderly men and women supplemented with a nutrition cocktail of beta-hydroxy-beta-methylbutyrate (HMB), L-arginine, and L-lysine. JPEN J Parenter Enteral Nutr. 2009;33(1):71-82.

37. Fujita S, Volpi E. Amino acids and muscle loss with aging. J Nutr. 2006;136(1 Suppl):277S-280S.

38. Wu H, Xia Y, Jiang J, Du H, Guo X, Liu X, Li C, et al. Effect of beta-hydroxy-beta-methylbutyrate supplementation on muscle loss in older adults: a systematic review and meta-analysis. Arch Gerontol Geriatr. 2015;61(2):168-175.

39. Tanner SB, Harwell SA. More than healthy bones: a review of vitamin D in muscle health. Ther Adv Musculoskelet Dis. 2015;7(4):152-159.

40. Landi F, Marzetti E, Martone AM, Bernabei R, Onder G. Exercise as a remedy for sarcopenia. Curr Opin Clin Nutr Metab Care. 2014;17(1):25-31. 